\title{
Hubungan Kadar Feritin Serum dengan Fungsi Kognitif Berdasarkan Pemeriksaan Status Mini-Mental (MMSE) pada Penyandang Thalassemia Anak
}

\author{
Fathiyah Ma’ani, Eddy Fadlyana, Sri Endah Rahayuningsih \\ Departemen Ilmu Kesehatan Anak Fakultas Kedokteran Universitas Padjadjaran/Rumah Sakit Hasan Sadikin, Bandung
}

Latar belakang. Penyandang thalassemia yang mendapat transfusi rutin tanpa kelasi besi yang optimal dapat menyebabkan kelebihan besi yang memicu stres oksidatif dan dapat mempercepat proses degenerasi di otak.

Tujuan. Menentukan hubungan kadar feritin serum dengan fungsi kognitif.

Metode. Penelitian analitik dengan rancangan potong lintang terhadap 95 penyandang thalassemia anak berusia di atas 10 tahun pada bulan April sampai Mei 2015. Pemilihan subjek dilakukan secara consecutive sampling. Fungsi kognitif dinilai berdasarkan tes mini mental state examination (MMSE). Kadar feritin serum dan faktor lain yang berhubungan dengan fungsi kognitif dianalisis menggunakan multipel regresi.

Hasil. Subjek penelitian terdiri dari 95 anak, anak laki-laki 46 orang $(48,4 \%)$ dan anak perempuan 49 orang 51,6\%. Rerata(SB) kadar feritin serum 4355,9 (2149) $\mu \mathrm{g} / \mathrm{L}$. Berdasarkan pemeriksaan MMSE didapatkan rerata(sb) skor 29,6 (3,9). Terdapat hubungan antara feritin serum dan fungsi kognitif $(\mathrm{p}=0,040)$. Faktor lain yang berhubungan adalah pendidikan anak, pendidikan ibu dan frekuensi transfusi.

Kesimpulan. Kadar feritin serum berhubungan dengan skor MMSE. Sari Pediatri 2015;17(3):163-8.

Kata kunci: thalassemia, anak, feritin, fungsi kognitif, MMSE

\section{The Assosiation between Ferritin Serum Level and Cognitive Function based on Mini-mental State Examination (MMSE) in Thalassemia children}

Fathiyah Ma’ani, Eddy Fadlyana, Sri Endah Rahayuningsih

Background. Repeated blood transfusions without optimal iron chelator causing iron overload that trigger oxidative stress and accelerate degeneration process in brain.

Objective. To determine cognitive function and its relationship with ferritin serum level.

Methods. An analytical cross-sectional study design of the 95 children aged over 10 years old from April to May 2015. Cognitive function was assessed by Mini-Mental State Examination (MMSE). Ferritin serum level and counfounding factors were analyzed using multivariat regression.

Result. Subjects were consisted of 95 children, 46 male (48.4\%) and 49 female (51.6\%). We performed MMSE test on subjects. Mean ferritin serum level (SD) was 4355,9(2149) $\mu \mathrm{g} / \mathrm{L}$, with the range of 698-9440 $\mu \mathrm{g} / \mathrm{L}$. Mean MMSE score(sd) was 29.6 (3.9) with the range of $17-35$.. Ferritn serum level have relationship with cognitive function $(P=0,040)$. Child education level, the frequency of transfusion, and mother education had relationship with cognitive function.

Conclusion. Ferritin serum level have relationship with MMSE score. Sari Pediatri 2015;17(3):163-8.

Keywords: thalassemia, children, ferritin, cognitive functions, MMSE

\footnotetext{
Alamat korespondensi:

Dr. Fathiyah Ma’ani. Departemen Ilmu Kesehatan Anak Fakultas Kedokteran Universitas Padjadjaran/Rumah Sakit Dr. Hasan Sadikin. Jl. Pasteur No.38 Bandung 40163, Indonesia, Tel. +62-22-3035957. E-mail: fathiyah.arioseno@gmail.com
} 
Transfusi rutin dan peningkatan absorbsi besi intestinal pada penyandang thalassemia dapat menyebabkan kelebihan besi diberbagai organ termasuk otak. ${ }^{1-3}$ Kelator besi yang tidak adekuat akan semakin memperberat kelebihan besi. ${ }^{4}$ Besi bebas atau non transferrin bound iron (NTBI) bersifat toksik terhadap organ tubuh melalui reaksi fenton menghasilkan radikal bebas yang dapat menyebabkan stres oksidatif dan mempercepat degenerasi sel..$^{5-7}$

Penyandang thalassemia memiliki risiko tiga kali lipat untuk memiliki gangguan fungsi kognitif dan intelektual sehingga sering mengalami masalah dalam lingkungan sosial, pekerjaan dan komunikasi. ${ }^{8}$ Fungsi kognitif dipengaruhi oleh faktor biologis dan lingkungan. ${ }^{9}$ Faktor lingkungan yang diketahui berhubungan dengan fungsi kognitif adalah status sosialekonomi, status gizi. Keadaan ini dapat menyebabkan gangguan belajar. Malnutrisi kronis juga diketahui dapat menurunkan atensi anak. ${ }^{10}$ Faktor lain yang juga berhubungan dengan perkembangan fungsi kognitif anak adalah pendidikan orangtua terutama ibu. ${ }^{11}$ Pengetahuan mengenai hubungan fungsi kognitif pada penyandang thalassemia dengan jenis kelamin, keadaan hipoksia kronik, onset transfusi, dan keadaan hemosiderosis sampai saat ini masih meragukan. ${ }^{12,13}$ Pemeriksaan fungsi kognitif pada penyandang thalassemia seharusnya dilakukan secara rutin sehingga apabila dicurigai atau didapatkan adanya gangguan kognitif, dapat segera diberikan intervensi. ${ }^{7}$ Penapisan fungsi kognitif dengan pemeriksaan status mini mental (MMSE) dapat digunakan klinik. Tes MMSE memiliki senisitivitas dan spesifisitas yang baik dalam menapis gangguan fungsi kognitif. ${ }^{14,15}$

Saat ini, kadar feritin serum penyandang thalassemia anak di RSUP Dr. Hasan Sadikin masih tinggi dan pemeriksaan fungsi kognitif belum rutin dilakukan. Penelitian mengenai hubungan kadar feritin serum dan fungsi kognitif sebelumnya masih memberikan hasil yang meragukan sehingga penelitian ini bertujuan untuk menentukan hubungan kadar feritin serum dan fungsi kognitif pada penyandang thalassemia anak di RSUP Dr. Hasan Sadikin.

\section{Metode}

Penelitian dilakukan di Departemen/SMF Ilmu Kesehatan Anak Rumah Sakit Dr. Hasan Sadikin Bandung pada bulan April-Mei 2015. Persetujuan tertulis (informed consent) diberikan orangtua atau wali setelah mendapat informasi secara lengkap dan mengerti untuk mengikutsertakan anaknya dalam penelitian. Kriteria inklusi adalah berusia $>10$ tahun, terdiagnosis thalassemia dan mendapat transfusi rutin, serta tidak memiliki gangguan dengar. Kriteria eksklusi adalah memiliki kelainan kongenital sindrom Down, menderita penyakit kronik lain selain thalassemia (seperti keganasan, tuberkulosis, hepatitis kronik, penyakit jantung bawaan, gagal ginjal kronik, epilepsi, diabetes militus).

Penelitian analitik dengan rancangan potong lintang. Pemilihan sampel dilakukan secara consecutive sampling pada semua penyandang thalassemia anak yang memenuhi kriteria inklusi yang kontrol rutin di Poliklinik Thalassemia Anak RSUP Dr. Hasan Sadikin, Bandung. Subjek yang memenuhi kriteria inklusi dicatat data dasar dari rekam medis, dilakukan anamnesis, pemeriksaan fisik, dan pengukuran status antropometri. Subjek kemudian dilakukan pemeriksaan fungsi kognitif dengan tes MMSE. Kadar $\mathrm{Hb}$ rata-rata sebelum transfusi dan kadar feritin 3 bulan terakhir dicatat berdasarkan data rekam medik atau data Laboratorium Patologi Klinik RSUP Dr. Hasan Sadikin. Karakteristik subjek penelitian disajikan secara deskriptif. Hubungan kadar feritin serum pada fungsi kognitif dianalisis menggunakan analisis bivariat dan analisis multivariat. Penelitian ini telah mendapat persetujuan dari Komite Etik Penelitian Fakultas Kedokteran Universitas Padjadjaran/RS Dr. Hasan Sadikin, Bandung dengan nomor: 258/UN6.C1.3.2/ KEPK/PN/2015.

\section{Hasil}

Persentase subjek laki-laki dibanding perempuan $48,4 \%$ dan $51,6 \%$. Status pendidikan orangtua Didapatkan status tingkat pendidikan ayah rendah 45,3\%, pendidikan ibu rendah $39,5 \%$, penghasilan orangtua rendah $18 \%$, sedang $61 \%$, dan tinggi $20 \%$. Dengan demikian, subjek penelitian mayoritas dengan penghasilan menengah ke bawah. Berdasarkan WHO Child Growth reference, 62\% tinggi badan menurut usia pada subjek penelitian stunted dan severelly stunted dan lebih $90 \%$ indeks massa tubuh menurut usia subjek penelitian berada pada area median (Tabel 1). Kadar feritin serum pada penelitian didapatkan rerata(SB) $4355,9(2149) \mu \mathrm{g} / \mathrm{L}$, median $3804 \mu \mathrm{g} / \mathrm{L}$ dengan rentang 
698-9440 $\mu \mathrm{g} / \mathrm{L}$ dengan skor MMSE rerata(SB) 29,6(3,9). Subjek penelitian dengan fungsi kognitif normal 81,1\% dan 18,9\% probable gangguan kognitif. Analisis bivariat dilakukan untuk megetahui hubungan antara variabel penelitian dan skor MMSE (Tabel 2). Hubungan antara variabel bebas dengan terikat dapat diketahui dengan menggunakan analisis regresi linier. Variabel bebas yang dianalisis multivariat bila analisis bivariat mempunyai nilai $\mathrm{p}<0,25$.

Berdasarkan Tabel 3, 31\% variasi skor MMSE dipengaruhi oleh kadar feritin serum, pendidikan anak, pendidikan ibu, dan frekuensi transfusi. Faktor yang memiliki pengaruh paling bermakna adalah pendidikan anak dan frekuensi transfusi.

Tabel 1. Karakteristik pasien thalassemia anak $(\mathrm{n}=95)$

\begin{tabular}{lll}
\hline Jenis kelamin & Jumlah & $\%$ \\
$\quad$ Laki-laki & & \\
$\quad$ Perempuan & 46 & 48,4 \\
Usia (tahun) & 49 & 51,6 \\
$\quad 10-12$ & & \\
$12->14$ & 69 & 72,6 \\
Pendidikan anak (tahun) & 26 & 27,4 \\
$\quad$ Rerata (SB) =5 & & \\
Median =5,3(1,6) & & \\
Rentang =0-9 & & \\
Pendidikan ayah & & \\
SD & 24 & 25,3 \\
SMP & 19 & 20,0 \\
SMA & 45 & 47,3 \\
Diploma/Sarjana & 7 & 7,4 \\
Pendidikan ibu & & \\
SD & 18 & 19 \\
SMP & 29 & 30,5 \\
SMA & 38 & 40,0 \\
Diploma/Sarjana & 10 & 10,5 \\
Penghasilan orangtua & & \\
Rendah & 17 & 18,0 \\
Sedang & 58 & 61,0 \\
Tinggi & 20 & 21,0 \\
Status antropometri & & \\
TB menurut usia & & \\
Normal & 36 & 38,0 \\
Stunted & 33 & 34,7 \\
Severelly stunted & 26 & 27,3 \\
Indek massa tubuh menurut usia & & \\
Median & 86 & 90,5 \\
$\quad<-2$ SB & 9 & 9,5 \\
<-3 SB & 0 & 0 \\
\hline
\end{tabular}

\section{Pembahasan}

Sampai saat ini thalassemia belum dapat disembuhkan, tetapi dengan tata laksana yang optimal maka kualitas dan kelangsungan hidup penyandang thalassemia dapat meningkat. Saat ini, di Jawa Barat, tercatat 2759 penyandang thalassemia berat (data POPTI Bandung, 2014). Data Rumah Sakit Dr. Hasan Sadikin didapatkan 656 pasien thalassemia yang mendapatkan pelayanan rutin dengan rentang usia 0-14 tahun berjumlah 381 orang. Salah satu masalah yang dihadapi dalam tatalaksana pasien thalassemia di RSUP Dr. Hasan Sadikin adalah perhatian yang kurang dalam mendeteksi komplikasi non klinis lain yang dapat terjadi, seperti gangguan fungsi kognitif. Penyandang thalassemia memiliki risiko tiga kali lipat untuk memiliki gangguan fungsi kognitif dan intelektual sehingga sering mengalami masalah dalam lingkungan sosial, pekerjaan, dan komunikasi. ${ }^{8}$ Penelitian kami merupakan penelitian pertama yang menapis gangguan fungsi kognitif pada pasien thalassemia dengan menggunakan tes MMSE di Rumah Sakit Umum Pusat Dr. Hasan Sadikin.

Kami mengikutsertakan 95 subjek yang memenuhi kriteria inklusi dengan persentase laki-laki dibanding perempuan $48,4 \%$ dan $51,6 \%$. Subjek penelitian berperawakan pendek $62 \%$. Hampir seluruh subjek penelitian memiliki kadar feritin tinggi dan memerlukan kelasi besi. Rerata (SB) kadar feritin serum adalah $4355,9(2149) \mu \mathrm{g} / \mathrm{L}$. Kadar feritin penelitian kami $2880,0(1504,1) \mu \mathrm{g} / \mathrm{L}$ lebih tinggi dari penelitian Monastero dkk. ${ }^{12}$ Kadar feritin yang tinggi disebabkan lebih dari 50\% subjek penelitian tidak mendapatkan kelasi besi optimal. Kadar hemoglobin pretransfusi rerata subjek penelitian berkisar 5-8 g/dL $(83,2 \%)$. Hal tersebut disebabkan kepatuhan yang kurang untuk melakukan transfusi rutin. Sosial ekonomi keluarga yang rendah merupakan faktor yang berperan dalam kepatuhan ini.

Pemeriksaan status mini mental (MMSE) merupakan tes penapisan fungsi kognitif yang digunakan secara luas dan merupakan alat pemeriksaan yang mudah, murah, dan sederhana. Tes ini dapat menjadi acuan untuk penilaian fungsi kognitif di klinik. ${ }^{16}$ Berdasarkan skor MMSE didapatkan rerata (SB) 29,6 $(3,9)$; median 30 dengan rentang skor 17-35 dan bila dikelompokkan berdasarkan interpretasi skor didapatkan 18 subjek probable gangguan kognitif 
Tabel 2. Skor MMSE berdasarkan karakteristik subjek penelitian

\begin{tabular}{|c|c|c|c|c|c|}
\hline \multirow[t]{2}{*}{ Variabel } & \multicolumn{4}{|c|}{ Skor MMSE } & \multirow[t]{2}{*}{ Nilai $p$} \\
\hline & $\mathrm{N}$ & Rerata(SB) & Median & Rentang & \\
\hline \multicolumn{6}{|l|}{ Pendidikan ayah } \\
\hline SD & 24 & $28,75(4,55)$ & 29,00 & $19-35$ & \multirow[t]{4}{*}{$0,129^{*}$} \\
\hline SMP & 19 & $28,95(3,24)$ & 29,00 & $22-34$ & \\
\hline SMA & 45 & $30,00(3,88)$ & 31,00 & $17-35$ & \\
\hline Diploma/Sarjana & 7 & $32,29(2,92)$ & 33,00 & $28-35$ & \\
\hline \multicolumn{6}{|l|}{ Pendidikan ibu } \\
\hline SD & 18 & $27,89(3,46)$ & 28,00 & $22-34$ & \multirow[t]{4}{*}{$0,049^{*}$} \\
\hline SMP & 29 & $29,24(4,16)$ & 29,00 & $19-35$ & \\
\hline SMA & 38 & $30,32(4,09)$ & 31,50 & $17-35$ & \\
\hline Diploma/Sarjana & 10 & $31,40(2,27)$ & 31,00 & $28-35$ & \\
\hline \multicolumn{6}{|l|}{ Penghasilan orangtua } \\
\hline Rendah & 17 & $29,06(3,59)$ & 29,00 & $22-35$ & \multirow[t]{3}{*}{$0,669^{*}$} \\
\hline Sedang & 58 & $29,55(4,38)$ & 30,50 & $17-35$ & \\
\hline Tinggi & 20 & $30,40(2,74)$ & 30,00 & $27-35$ & \\
\hline \multicolumn{6}{|l|}{ Status antropometri } \\
\hline \multicolumn{6}{|l|}{ TB menurut usia } \\
\hline Stunted & 33 & $29,58(3,50)$ & 29,00 & $22-35$ & \multirow[t]{3}{*}{$0,840^{*}$} \\
\hline Severelly stunted & 26 & $29,35(4,38)$ & 30,50 & $17-35$ & \\
\hline Normal & 36 & $29,92(4,08)$ & 31,00 & $19-35$ & \\
\hline \multicolumn{6}{|c|}{ Indek massa tubuh menurut usia } \\
\hline Median & 86 & $29,58(3,93)$ & 30,00 & $17-35$ & \multirow{3}{*}{$0,692^{* *}$} \\
\hline$<-2$ SB & 9 & $30,22(4,20)$ & 29,00 & $23-35$ & \\
\hline$<-3 \mathrm{SB}$ & 0 & 0 & 0 & 0 & \\
\hline \multicolumn{6}{|c|}{ Kadar feritin $(\mu \mathrm{g} / \mathrm{L})$} \\
\hline \multicolumn{6}{|c|}{$\operatorname{Rerata}(S B)=4355,9(2149,3)$} \\
\hline Median $=3804$ & & & & & \\
\hline Rentang = 698-9440 & & & & & \multirow{4}{*}{$0,063^{*}$} \\
\hline$<1000$ & 2 & $29,00(2,82)$ & 29,00 & $27-31$ & \\
\hline $1000-2500$ & 20 & $31,35(3,61)$ & 32,50 & $24-35$ & \\
\hline$>2500$ & 73 & $29,19(3,96)$ & 29,00 & $17-35$ & \\
\hline \multicolumn{6}{|l|}{ Kadar Hb pretransfusi(g/dL) } \\
\hline$<5$ & 1 & 26,00 & 26,00 & 26 & \multirow[t]{3}{*}{$0,237^{*}$} \\
\hline $5-8$ & 79 & $29,44(4,07)$ & 30,00 & $17-35$ & \\
\hline $8-10$ & 15 & $30,93(3,01)$ & 31,00 & $26-35$ & \\
\hline \multicolumn{6}{|l|}{ Frekuensi transfusi } \\
\hline 2 minggu sekali & 14 & $27,36(4,53)$ & 27,50 & $19-35$ & \multirow[t]{4}{*}{$0,002^{*}$} \\
\hline 3 minggu sekali & 18 & $27,72(3,92)$ & 28,50 & $17-35$ & \\
\hline 4 minggu sekali & 54 & $30,43(3,31)$ & 31,00 & $22-35$ & \\
\hline$>1$ bulan sekali & 9 & $32,33(3,77)$ & 34,00 & $25-35$ & \\
\hline \multicolumn{6}{|l|}{ Jenis kelator besi } \\
\hline Desferoksamin & 5 & $31,00(2,45)$ & 31,00 & $29-35$ & \multirow[t]{4}{*}{$0,860^{*}$} \\
\hline Deferipron & 59 & $29,59(4,19)$ & 30,00 & $19-35$ & \\
\hline Deferasiroks & 29 & $29,55(3,80)$ & 30,00 & $17-35$ & \\
\hline Tidak mendapat terapi & 2 & $29,00(2,83)$ & 29,00 & $27-31$ & \\
\hline
\end{tabular}

Ket: "Kruskal Wallis "Mann Whitney 
Fathiyah Ma'ani dkk: Hubungan kadar feritin serum dengan fungsi kognitif berdasarkan MMSE

Tabel 3. Analisis multivariat faktor yang berhubungan dengan skor MMSE

\begin{tabular}{lcccc}
\hline Variabel & Koef $\beta$ & SE & $\mathrm{T}_{\text {hirung }}$ & Nilai p \\
\hline Feritin & $-0,0003$ & 0,0002 & $-2,082$ & 0,040 \\
Pendidikan anak (tahun) & 0,722 & 0,233 & 3,10 & 0,003 \\
Pendidikan ibu & 0,809 & 0,351 & 2,304 & 0,024 \\
Frekuensi transfusi & 1,304 & 0,424 & 3,077 & 0,003 \\
Konstanta & 21,903 & & & \\
\hline
\end{tabular}

Ket: $\mathrm{r}^{2}$ multipel $=31,5 \% ; \mathrm{P}<0,001$

$(18,9 \%)$. Anak thalassemia memiliki risiko tiga kali lipat untuk memiliki gangguan fungsi kognitif dan intelektual sehingga sering mengalami masalah dalam lingkungan sosial, pekerjaan, dan dalam berkomunikasi. $^{8}$

Kami mendapatkan hubungan antara kadar feritin serum dengan fungsi kognitif berdasarkan skor MMSE. Berbeda dengan penelitian Monastero $\mathrm{dkk}^{12}$ yang melaporkan tidak terdapat hubungan antara kadar feritin serum dan dengan skor MMSE. Hal tersebut mungkin disebabkan kadar feritin serum pada penelitian Monastero dkk lebih rendah dibandingkan pada penelitian kami. ${ }^{12}$ Kadar feritin tinggi dapat mengganggu fungsi kognitif. Kelebihan besi, pada keadaan hemokromatosis, menyebabkan terjadinya peningkatan kadar tranferin serum dan transportasi besi melewati sawar darah otak. Besi yang masuk melalui sawar otak menyebabkan terjadinya akumulasi besi di otak. ${ }^{17}$ Kelebihan besi menyebabkan transferin tersaturasi penuh sehingga terbentuklah NTBI. Besi dapat mengatalisasi pembentukan radikal bebas yang berbahaya dalam kondisi aerob. Toksisitas besi didasarkan pada reaksi kimia Fenton dan HaberWeiss, besi dapat mengatalisis pembentukan radikal bebas reactive oxygen species(ROS), seperti radikal hidroksil dan pembentukan peroksidasi lipid melalui reaksi dengan hidrogen peroksidase $\left(\mathrm{H}_{2} \mathrm{O}_{2}\right)$. Reactive oxygen species dapat mudah berikatan dengan berbagai molekul, seperti protein, DNA, lipid, dan antioksidan. Peningkatan kadar radikal bebas yang melebihi kapasitas antioksidan disebut stres oksidatif. Stres oksidatif akan mempercepat degenerasi jaringan. ${ }^{18}$ Hasil penelitian kami sesuai dengan penelitian casecontrol oleh Duman $\mathrm{dkk}^{19}$ yang melaporkan bahwa fungsi kognitif pada beta thalassemia diketahui lebih rendah secara signifikan.

Fungsi kognitif dipengaruhi oleh faktor biologis dan lingkungan. ${ }^{9}$ Pada penelitian kami, fungsi kognitif berhubungan dengan pendidikan anak. Hal tersebut sesuai dengan Ouvrier ${ }^{14}$ yang melaporkan bahwa skor MMSE berhubungan dengan usia mental. Kesempatan mendapatkan pendidikan merupakan salah satu faktor lingkungan yang berperan dalam perkembangan fungsi kognitif. ${ }^{9}$

Frekuensi transfusi berhubungan dengan fungsi kognitif. Frekuensi transfusi berkaitan dengan keadaan anemia yang terjadi pada penyandang thalassemia. Keadaan anemia diketahui akan meningkatkan absorbsi besi intestinal sebagai kompensasi terhadap keadaan anemia. Pemberian transfusi rutin sebagai tata laksana untuk mengatasi keadaan anemia dapat menyebabkan kelebihan besi. Dua keadaan tersebut akan berperan pada kejadian kelebihan besi pada penyandang thalassemia dan akan menyebabkan akumulasi besi diberbagai organ termasuk otak. ${ }^{1,2}$ Keadaan anemia juga mengakibatkan perfusi jaringan terganggu. Penelitian mengenai hipoksia kronik pada penyakit paru menunjukan adanya gangguan pada kognitif terutama pada domain memori, bahasa verbal, atensi, dan berpikir abstrak. ${ }^{20}$ Armstrong dkk ${ }^{21}$ melaporkan keadaan anemia kronik dan berat berkaitan dengan fungsi kognitif dengan atau tanpa adanya gambaran brain injury pada otak secara MRI.

Tingkat pendidikan orangtua memiliki hubungan dengan fungsi kognitif anak. Tingkat pendidikan ibu berkaitan dengan stimulasi dini pada perkembangan kognitif seorang anak. ${ }^{22}$ Berkman $\mathrm{dkk}^{11}$ menilai fungsi kognitif pada populasi anak yang terinfeksi parasit menunjukan tingkat pendidikan ibu memiliki hubungan dengan kognitif anak.

Keterbatasan penelitian kami di antaranya adalah kadar feritin yang dianalisis bukan kadar feritin aktual pada saat dilakukan pemeriksaan fungsi kognitif, tetapi menggunakan kadar feritin dalam 3 bulan terakhir. Penelitian ini belum melibatkan semua usia penyandang thalassemia. 


\section{Kesimpulan}

Penapisan fungsi kognitif pada penyandang thalassemia dapat dilakukan dengan menggunakan tes MMSE. Terdapat hubungan bermakna antara kadar feritin serum dengan fungsi kognitif berdasarkan skor MMSE. Faktor-faktor lain yang juga berhubungan dengan fungsi kognitif pada penyandang thalassemia adalah pendidikan anak, pendidikan ibu dan frekuensi transfusi.

\section{Daftar pustaka}

1. Youdim M. Deficiency and excess of iron in brain function and dysfunction. Nutr Rev 2001;59:S83-5.

2. Schenck J. JF Magnetic resonance imaging of brain iron. J Neurol Sci 2003;207:99-102.

3. Weatherall D, Clegg J. Inherited haemoglobin disorders: an increasing global health problem. Bull World Health Organ 2001;79:704-12.

4. Hoffbrand A, Taher A, Cappellini M. How I treat transfusional iron overload. Blood J Hematology 2012;120:3657-69.

5. Sian-Hulsmann J, Mandel S, Youdim M, Riederer P. The relevance of iron in the pathogenesis of Parkinson's disease. J Neurochem 2011;118:939-57.

6. Weinreb O, Amit T, Mandel S, Kupershmidt L. Neuroprotective multifunctional iron chelators: from redox-sensitive process to novel therapeutic opportunities. Antioxid Redox Signal 2010:919-49.

7. Raafat N, Safy UE, Khater N, Hassan T, Hassan B, Siam A, dkk. Assessment of cognitive function in children with beta thalassemia mayor: a cross-sectional study. J Child Neurol 2014:1-6.

8. Sabry N, Salama K. Cognitive abilities, mood changes and adaptive functioning in children with beta thalassemia. Current Psychiatri 2009;16:244-54.

9. Dutta J. What are the factors affecting cognitive development of children? Diakses 12 Maret 2015. Tersedia dari: http://wwwpreservearticlescom/2011100714884/what-arethe-factors-affecting-cognitive-development-of-childrenhtml.
10. Mc Ardley JH, Ashworth JC. Micronutriens in fetal growth and development. Brit Med Bull 1999;55:499-510.

11. Berkman DS, Lescano AG, Gilman RH, Lopez SL, Black MM. Effects of stunting, diarrhoeal disease, and parasitic infection during infancy on cognition in late childhood: a follow-up study. The Lancet 2002;359:564-71.

12. Monastero R, Monastero G, Ciaccio C. Cognitive deficits in beta-thalassemia major. Acta Neurol Scand 2000;102:162-8.

13. Sinniah D, Vignaendra V, Ahmad K. Neurological complications of b-thalassaemia major. Arch Dis Child 1977;52:977-9.

14. Ouvrier R, Goldsmith R, Ouvrier S, Williams I. The value of the mini-mental state examination in childhood: a preliminary study. J Child Neurol 1993;8:145-8.

15. Sigit IA, Aminah S, Kurniani N. Validasi mini mental state examination (MMSE) modifikasi Ouvrier sebagai alat penapisan fungsi kognitif anak usia 8-11 tahun di tiga sekolah di kota Bandung (tesis). Bandung: Universitas Padjadjaran Bandung. 2005

16. Jain M, Passi G. Assessment of a modified mini-mental scale for cognitive functions in children. Indian Pediatric 2005;42:907-12.

17. Evan-Gelder W, Huijskes-Heins M, Cleton-Soeteman M. Iron uptake in blood-brain barrier endothelial cells cultured in iron-depleted and iron-enriched media. J Neuroche 1998;998:1134-40.

18. Sadrzadeh $\mathrm{SH}$, YasiSaffari. Iron and brain disorder. Am J Clin Pathol. 2004;21(Suppl 1):S64-S70.

19. Duman O, Arayci S, Fettahoglu E. Neurocognitive function in patient beta thalessemia major. Pediart Int 2011;53:519-23.

20. Areza-Fegyveres R, Kairalla RA, Carvalho CR, Nitrini R. Cognition and chronic hypoxia in pulmonary diseases. Dement Neuropsychol 2010;4:14-22.

21. Armstrong FD. Thalassemia And Learning Neurocognitive Functioning In Children. Ann NY Acad Sci 2005;1054:283-9.

22. Schady N. Parents' Education, Mothers' Vocabulary, and Cognitive Development in Early Childhood: Longitudinal Evidence From Ecuador. American Journal of Public Health. 2011 101:2299-307. 